\title{
TRADISI NGIDANG (KAJIAN PERUBAHAN DAN PERGESERAN TRADISI NGIDANG DI MASYARAKAT KELURAHAN 30 ILIR PALEMBANG)
}

\author{
Sri Septiyani ${ }^{1}$ Bety $^{2}$, Nurfitri Hadi ${ }^{3}$ \\ ${ }^{123}$ Program Studi Sejarah Peradaban Islam Fakultas Adab dan Humaniora \\ UIN Raden Fatah Palembang. \\ Gmail : srisepti1997@gmail.com
}

\begin{abstract}
Abstrak
Artikel ini bermaksud memberikan gambaran pada penyebab terjadinya pergeseran, serta dampak yang disebabkan akibat terjadinya perubahan tradisi dalam suatu masyarakat di kelurahan 30 Ilir Palembang.Tujuan penelitian ini adalah mendeskripsikan penyebab terjadinya pergeseran Tradisi Ngidang di kelurahan 30 Ilir Palembang. jenis penelitian ini adalah deskriptif kualitatif dengan sumber data primer terdiri dari: pelaksana Ngidang, masyarakat $30 \mathrm{Ilir}$, kepala Adat, tokoh agama. dan sumber sekunder terdiri dari studi pustaka, dokumentasi, dan jurnal. Teknik pengumpulan data mengunakan metode wawancara, observasi, dan dokumentasi. Hasil penelitian ini adalah perubahan serta pergeseran tradisi Ngidang yang disebabkan beberapa Faktor ,faktor ekonomi, perkembangan zaman, garis keturunan, serta modernisasi. Dampak yang disebabkan dari terjadinya pergeseran tradisi Ngidang adalah dibagi menjadi 2 yaitu Damapak Negatif: lemahnya intensitas interaksi masyarakat, hubungan antar masyarakat tidak kuat, menjadikan hilangnya budaya lokal atau tradisi yang dimiliki masyarakat sebagai ciri khas masyarakat. Dampak positif yaitu semakin berkembang nya pola pikir manusia yang menghasilkan inovasi terbaru yang menghasilkan peningkatan sektor kehidupan.
\end{abstract}

Kata Kunci:- Ngidang, -Perubahan dan Pergeseran, -Tradisi Memuliakan Tamu.

\begin{abstract}
This article intends to provide an overview of the causes of the shift, as well as the impact caused by changing traditions in a community in 30 Ilir Palembang Village. The purpose of this study is to describe the causes of the shift in the Ngidang Tradition in 30 Ilir Palembang Village. This type of research is qualitative descriptive with primary data sources consisting of: field executors, 30 Ilir communities, traditional heads, religious leaders. and secondary sources consisting of literature studies, documentation, and journals. The data collection technique uses the interview, observation, and documentation methods. The results of this study are changes and shifts in the Ngidang tradition caused by several factors, economic factors, times of development, lineage, and modernization. The impact caused by the shift in the Ngidang tradition is divided into 2, namely Negative Damapak: the weak intensity of community interaction, the relationship between communities is not strong, making the loss of local culture or traditions owned by the community as a characteristic of society. The positive impact is the development of the human mindset that produces the latest innovations that result in an increase in the life sector.
\end{abstract}

Keywords: - Ngidang, - Change and shift, - Tradition honors guests 


\section{A. PENDAHULUAN}

Keanekaragaman budaya yang dimiliki bangsa Indonesia yang senantiasa dijaga dan dilestarikan secara turun-temurun adalah merupakan gambaran kekayaan bangsa Indonesia menjadi modal dan landasan pembangunan dan pengembangan kebudayaan nasional. Pengembangan kebudayaan nasional itu sendiri berarti memelihara, melestarikan, menghadapkan, memperkaya, menyebarluaskan, memanfaaatkan, dan meningkatakan mutu serta daya guna kebudayaan ${ }^{1}$.

Tradisi dalam bahasa inggris yakni tradition, bahasa perancis yakni tradicio yang keduanya memiliki arti yang luas. Tradisi menurut KBBI adalah adat istiadat yang turun temurun dari nenek moyang yang sudah dilaksanakan oleh masyarakat, penilaian maupun anggapan bahwa cara-cara yang sudah ada adalah yang paling baik dan benar, menurut WJS Poerwadaminto (1976), Tradisi adalah seluruh sesuatu yang melekat pada kehidupan dalam masyarakat yang dijalankan secara terus menerus, seperti: adat, budaya, kebiasaan, dan kepercayaan.

Dalam pengertian lain tradisi adalah adat-istiadat atau kebiasaan yang turun temurun yang masih dijalankan dimasyarakat. Dalam suatu masyarakat muncul semacam penilaian bahwa caracara yang sudah ada merupakan cara yang terbaik untuk menyelesaikan persoalan ${ }^{2}$.

Masyarakat melayu dalam memuliakan tamu menjadi ciri khas tersendiri yang menjadi budaya lokal yang bercampur dengan islam, Dalam Islam pun memuliakan tamu adalah sebuah amal shalih yang pahalanya bukan saja akan dibalas oleh Allah di akhirat sebagai tabungan tapi juga akan mendapatkan balasan secara langsung di dunia yang akan segera dirasakan oleh pelakunya. Rasulullah shallallahu'alaihi wa sallam bersabda.

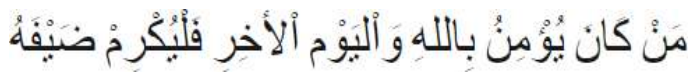

Artinya: Barang siapa yang beriman pada Allah dan hari akhir maka hendaklah dia memuliakan tamunya." (HR. Bukhari).

Namun dengan semakin berkembang nya suatu daerah, maka banyak tradisi-tradisi di Sumatera Selatan banyak dilupakan oleh Masyarakat Sumatera Selatan Terkhusus para generasi muda, malah tidak tahu sama sekali dengan tradisi Ngidang tersebut Padahal tradisi tersebut banyak akan makna positif yang ada dalam setiap prosesinya yang mengalami sebuah perubahan maupun pergeseran secara mengkhawatirkan.

Berdasarkan latar belakang diatas maka saya ingin meneliti tentang "Tradisi Ngidang" Sebagai budaya penyajian makanan di Palembang, kajian tentang pergeseran dan perubahan yang terjadi di tradisi Ngidang di masyarakat 30 Ilir Palembang karena tradisi tersebut merupakan tradisi menjamu tamu khas dari melayu khususnya di Palembang yang memiliki banyak nilai- nilai islam yang saat ini telah tergerus perubahan Zaman yang jarang dikenal dikalangan generasi muda, kemudian menurut penulis ada keunikan sendiri dimana para tamu sangat dilayani semua kebutuhannya saat acara Ngidang berlangsung dan sangat di hormati di tradisi ini, kemudian tradisi ini mengalami pergeseran dengan adanya budaya penyajian perancisan. Dan peneliti melihat belum adanya penulisan yang membahas lebih detail tentang Tradisi "Ngidang" sebagai budaya penyajian Palembang kajian tentang pergeseran tradisi Ngidang di masyarakat 30 Ilir Palembang.

\footnotetext{
${ }^{1}$ Dona Aprianti, “Tradisi Mappaci Dalam Perkawinan Masyarakat Bugis Di Desa Tanjung Kerang Kecamatan Babat Supat Kab. Muba”, Skripsi (Palembang: Fakultas Adab Dan Humaniora, UIN Raden Fatah Palembang), 2018. h, 3

2 Diakses dari blogspot.co.id./201207/definisi-dan-pengertian-tradisi.html artikel ini diakses tanggal 11 Agustus 2020 pukul. 13.30 wib.
} 


\section{B. TINJAUAN PUSTAKA}

Pembahasan mengenai Ngidang secara spesifik belum penulis temukan, dan tradisi Ngidang ini pernah dibahas oleh Fitriah dengan judul penelitiannya Nilai Kearifan Lokal Dalam Tradisi "Ngobeng" Di Desa Seri Bandung Kecamatan Tanjung Batu Kabupaten Ogan Ilir. Dalam penelitian Fitriah membahas tentang bagaimana tradisi Ngobeng di Desa Seri Bandung Kecamatan Tanjung Batu kabupaten Ogan Ilir dan nilai-nilai kearifan lokal yang terkandung dalam tradisi Ngobeng.

Selanjutnya Skripsi Tria Mauliza yang berjudul Pergeseran Budaya Dalam Masyarakat Pidie” Studi Pada Pakaian Adat Perkawinan Di Gambong Perlak Asan Kabupaten Pidie”. Yang membahas sebuah pergeseran yang terjadi di dalam masyarakat kabupaten Pidie. Dan penelitian yang dilakukan Suryana yang berjudul adat istiadat perkawinan Palembang, yang membahas serangkain adat perkawinan masyarakat Palembang serta membahas tahapan tahapan adat istiadat perkawinan masyarakat Palembang dan pergeseran yang terjadi pada adat istiadat perkawinan masyarakat Palembang.

Pergeseran tradisi Ngidang ini menandakan sebuah tradisi yang mulai ditinggalkan oleh masyarakat Palembang dan adanya faktor-faktor yang mempengaruhi terjadinya pergeseran yang terjadi di masyarakat.

\section{METODE PENELITIAN}

Penelitian ini termasuk penelitian deskriptif kualitatif yaitu penelitian yang dilakukan untuk memperoleh data deskriptif berupa kata-kata dalam bentuk lisan maupun tulisan.dan menggunkan metode etnografi yaitu studi penelitian tentang mengenai masyarakat dan sebuah kebudayaan. Penelitian dilalukan selama 8 (delapan bulan), dengan memilih kelurahan 30 Ilir Palembang sebagai locus penelitian ini. Selain melakukan teknik observasi partisipan penulis juga melakukan wawancara mendalam dengan ketua adat, tokoh masyarakat, masyarakat sekitar, serta informan lainnya yang mengetahui tentang Tradisi Ngidang di kelurahan 30 Ilir Palembang.

\section{HASIL DAN PEMBAHASAN}

\section{Profil Singkat Kelurahan 30 Ilir Palembang}

Palembang adalah sebuah kota di Provinsi Sumatera Selatan yang mana kota tersebut menjadi Ibu Kota dari Provinsi Sumatera Selatan (umumnya disingkat menjadi Sumsel) adalah provinsi di Indonesia yang terletak di bagian selatan Pulau Sumatra. Provinsi ini ibu kota di Palembang. Letak geografis, Sumatra Selatan berbatasan dengan provinsi Jambi di sebelah utara, provinsi Kep. Bangka-Belitung di sebelah Timur, Provinsi Lampung di sebelah Selatan dan Provinsi Bengkulu di sebelah Barat. Provinsi Palembang ini kaya akan sumber daya alam, seperti minyak bumi, gas alam dan batu bara. Selain itu, ibu kota provinsi Sumatra Selatan, Palembang, telah terkenal sejak dahulu karena menjadi pusat Kerajaan Sriwijaya ${ }^{3}$. Palembang memiliki banyak persebaran wilayah dari mulai kecamatan, Kelurahan, hingga taraf tingkatan wilayah RT maupun RW. Terdapat salah satu Kelurahan yaitu 30 Ilir yang menjadi lokasi penelitian. Kelurahan 30 Ilir beragam, ditinjau dari agama, sosial, budaya, dan ekonomi.

Dari data persebaran penduduk yang ada di Kelurahan 30 Ilir jumlah penduduk keseluruhan adalah 19.646 jiwa (per bulan Juli 2020). Untuk agama terdapat 5 Agama besar yaitu, Islam, Kristen, Katholik, Buddha, dan Hindu. Di Kelurahan 30 Ilir masyarakat nya ratarata bermata pencarian sebagai buruh, pegawai BUMN, pegawai Swasta, pedagang, PNS dan lain-lain.

Untuk keunggulan dari Kelurahan 30 Ilir Palembang terdapat sentra industri songket yang menjadi pusat pembuatan songket yang ada di Palembang. Songket adalah kerajinan tangan khas

\footnotetext{
${ }^{3}$ Diakses melalui https://id.wikipedia.org/wiki/Sumatra_Selatan pada tanggal 20 Desember 2020, pukul 14.19 wib.
} 
Kota Palembang yang telah turun-temurun dihasilkan oleh masyarakat Palembang dari zaman Kerajaan Sriwijaya hingga sekarang. ${ }^{4}$ Serta terdapat masjid tua dan adanya tradisi-tradisi yang dilakukan masyarakat dalam perayaan setiap hari-hari besar agama.

\section{Deskripsi Tradisi Ngidang}

Sumatera Selatan khususnya Palembang mempunyai adat-istiadat yang tidak dapat dipisahkan dengan historisitas dan peran interatif yang sangat besar dari raja-raja di masa Kesultanan Palembang. Hadirnya islam sebagai agama dan hukum resmi mengubah tidak hanya hukum pemerintah, bahkan budaya DLL. Di masyarakat Palembang terdapat tradisi dalam memuliakan dan menjamu tamu yang merupakan ciri khas masyarakat melayu yang menjadi khas dari suku melayu di Indonesia termasuk yang ada di Palembang. Yang sangat islami dan banyak memiliki nilai-nilai islam yang terkandung didalam berjalannya tradisi, salah satunya Tradisi Ngidang sebagai metode penyajian secara Tradisonal.

Tradisi Ngidang merupakan suatu tradisi masyarakat Palembang dalam penyajian makanan dalam acara pernikahan, serta kedurian yang menjadi budaya pada masyarakat Palembang. Bentuk dari hidangan ini merupakan segi empat dalam satu saperah yang beranggotakan 8 orang. Jumlah 8 dalam satu hidangan ini mempunyai makna filosofis yaitu mengartikan sebagai 24 jam waktu dalam sehari yang terbagi dalam 3 watu yaitu, 8 jam untuk beribadah, 8 jam untuk bekerja, dan 8 jam untuk beristirahat ${ }^{5}$.

Tradisi Ngidang ini menurut wawancara dengan Bapak Kemas Ari Pandji dan Bapak R.M Ali Hanafiah merupakan metode penyajian pada zaman kesultanan Palembang Darussalam yang bercorat Islam6 ${ }^{6}$. Dan dalam fatwa Sultan Mahmud Badaruddin II dalam tulisannya yaitu "Pelihara Akan Dirimu Dari Perbuatan Dan Perkataan Yang Menyalahi Syariat". Dari pernyataan tersebut dengan demikian dapat diduga bahwa masa kesultanan Palembang Darussalam bersikap ramah tamah dan sopan dalam menerima tamu ${ }^{7}$.

Namun pada Zaman sekarang Ngidang ini mengalami perubahan serta pergeseran yang sangat mengawatirkan, mulai dari hilangnya beberapa alat-alat yang digunakan hingga tradisi mulai ditinggalkan oleh masyarakat yang lebih memilih metode penyajian yang mereka anggap lebih praktis dan tidak merepotkan tentangga karena banyak memerlukan tenaga untuk proses Ngidang,hal tersebutlah yang membuat traisi ini mengalami pergeseran yang sangat mengawatirkan ${ }^{8}$.

\section{Perubahan dan Pergeseran Tradisi Ngidang di Masyarakat Kelurahan 30 Ilir Palembang}

Tabel 1. Data perubahan Tradisi Ngidang yang terjadi di masyarakat

\begin{tabular}{|c|c|}
\hline Sebelum terjadinya perubahan & Sesudah terjadinya Perubahan \\
\hline $\begin{array}{l}\text { 1) Menyiapkan semua konsumsi sebelum hari } \mathrm{H} \\
\text { hajatan yang mengunakan metode Ngidang } \\
\text { dengan gotong royong, bahu-membahu. }\end{array}$ & $\begin{array}{l}\text { 1) Menyiapkan konsumsi telah disiapkan oleh tuan } \\
\text { rumah. Dengan jasa catering prasmanan }\end{array}$ \\
\hline $\begin{array}{l}\text { 2) Pe-Ngobeng memakai baju melayu dan } \\
\text { dilakukan oleh laki- laki dan lebih teratur dan }\end{array}$ & $\begin{array}{l}\text { 2) Pe-Ngobeng sekarang bisa dilakukan oleh laki- } \\
\text { laki maupun perempuan. Sekarang peNgobeng }\end{array}$ \\
\hline
\end{tabular}

\footnotetext{
${ }^{4}$ Dokumen di Kelurahan 30 Ilir Palembang.

${ }^{5}$ Wawancara pribadi dengan Bapak R.M Ali Hanafiah (Pemuka Adat Palembang) 19 Desember 2020

${ }^{6}$ Wawancara pribadi dengan Bapak Kemas Ari Pandji (Sejarawan sumsel) pada tanggal 15 Desember 2020

${ }^{7}$ Nawiyanto, Eko Crys Endrayadi, Kesultanan Palembang Darusslam Sejarah dan Warisan Budayanya, (Jember: Jember University Press, 2016) H. 160.

${ }^{8}$ Fitriah, Nilai Kearifan Lokal Dalam Tradisi Ngobeng di Desa Seri Bandung Kecamatan Tanjung Batu, Kabupaten Ogan Ilir. Tamadun: Jurnal Kebudayaan dan Sastra Islam, Vol. 19 No. 2.2019.
} 


\begin{tabular}{|c|c|c|}
\hline & $\begin{array}{l}\text { sesusai dengan adab-adab ketentuan / aturan } \\
\text { sebagai pe-Ngobeng. }\end{array}$ & \\
\hline 3) & $\begin{array}{l}\text { Menyiapkan dan memasak dengan cara gotong } \\
\text { royong bersama tetangga }\end{array}$ & $\begin{array}{l}\text { 3) Sudah teralihkan oleh jasa catering dan Upah } \\
\text { Panggong. }\end{array}$ \\
\hline 4) & $\begin{array}{l}\text { Peralatan yang digunakan dari hasil kerajinan } \\
\text { tangan masyarakat Palembang }\end{array}$ & $\begin{array}{l}\text { 4) Sudah Tergantikan dengan bahan-bahan yang } \\
\text { berbahan Plastik dan mudah di jumpai. }\end{array}$ \\
\hline & $\begin{array}{l}\text { Mayarakat antusias saat ada masyarakat yang } \\
\text { sedekahan, baik kedurian, maupun hajatan } \\
\text { pernikahan. }\end{array}$ & $\begin{array}{l}\text { 5) Masyarakat kurang antusias saat adanya prosesi } \\
\text { Ngidang karena kerumitan ketika melakukan } \\
\text { metode Ngidang. }\end{array}$ \\
\hline
\end{tabular}

a. Bentuk perubahan dan pergeseran Ngidang

Bergesernya Tradisi Ngidang ini mendapatkan respon yang berbeda dari masyarakat, ada yang tidak setuju dengan berkurangnya minat masyarakat melestarikan metode Ngidang yang sebagai Tradisi Lokal masyarakat Palembang dan ada juga yang menyikapi pergeseran secara biasa saja seolah membiarkan tradisi tersebut hilang begitu saja, sesuai dengan perkembangan yang ada di zaman sekarang.

Perubahan itu terlihat dari berkurangnya pelaku tradisi "Ngidang" di Kelurahan 30 Ilir Palembang dan perubahan yang dilakukan masyarakat dalam tradisi Ngidang. Perubahan itu adalah sebagai berikut:

1. Perubahan dalam segi tata cara dan Proses Ngidang

Sebelum memulai rangkaian Ngidang, yang menjadi identik dari Ngidang ini adalah PeNgobeng dahulu PeNgobeng merupakan orang yang bertugas mengatur dan mengantarkan makan ke para tamu, menurut wawancara dengan bapak RM. Ahmad Nawawi "kalau dahulu peNgobeng di acara Ngidang ini, yang bertugas haruslah laki-laki dan memakai pakaian khas melayu Palembang dan identik dengan pakaian Palembang, kalau sekarang peNgobeng lebih kearah yang modern mulai peNgobeng memakai baju batik atau baju kemeja saja, terkadang peNgobeng juga hanya sebatas mengatur dan menyediakan makanan saja. kalau dahulu peNgobeng sangat mengatur keperluan dari para tamu dan sangat dilayani dengan baik oleh peNgobeng“"9.

Jadi, Perubahan terlihat dalam rangkaian tradisi Ngidang, dahulu masyarakat Palembang dalam metode penyajiannya mengunakan metode Ngidang dan peran peNgobeng sangat lah melayani kebutuhan para tamu, namun sekarang semua itu sudah jarang terlihat, hal tersebut dikarenakan beberapa masyarakat yang tidak ingin menggunakan tradisi tersebut karena peNgobeng selaku yang bertugas mengantarkan kebutuhan para tamu memerlukan tenaga yang banyak, hal tersebutlah membuat masyarakat sekitar meninggalkan tradisi Ngidang ${ }^{10}$.

2. Perubahan dalam segi keinginan masyarakat untuk melakukan penyajian "Ngidang".

Sebelum adanya perkembangan arus perubahan Masyarakat 30 Ilir dalam metode Penyajian Makanan mengunakan metode hidangan/Ngidang. Masyarakat lebih menikmati makanan secara hidangan dan dinilai lebih akrab dengan masyarakat lain, saling bercengrama, dan nilai gotong royong dan keberkahan lebih dirasakan saat Ngidang berlangsung. Namun perkembangan zaman yang mempengaruhi pada partisipasi masyarakat dalam mengunakan teknik hidangan saat acara-acara syukuran atapun acara lainnya

\footnotetext{
9 Wawancara Pribadi dengan bapak RM. Ahmad Nawawi pada tanggal 04 Januari 2021

10 Wawancara Pribadi dengan Bapak Ustman Aris (tokoh masyarakat) tanggal 04 Januari 2021
} 
Berdasarkan hasil wawancara dengan informan, penulis menyimpulkan perubahan dari segi masyarakat yang mengunakan tradisi Ngidang karena kerumitan ketika menggunakan metode Ngidang dan masyarakat lebih menginginkan metode yang ringkas dan praktis. dan adanya metode yang baru yaitu prasmanan/ lebih dikenal di masyarakat 30 Ilir prancisan yang di nilai lebih praktis, sehingga masyarakat lebih tertarik dan memilih menggunakan metode praktis atau metode perancisan.

3. Perubahan dari Segi Perlengkapan yang digunakan

Selain dua diatas perubahan pada tradisi Ngidang pada perlengkapan yang digunakan. Menurut wawancara dengan bapak Ahmad "saat ini Ngidang dilakukan oleh salah satu masyarakat 30 Ilir beberapa perlengkapan sudah mulai tergantikan dengan bentuk yang berbeda namun dengan wujud yang sama, contohnya saja perubahan yang terjadi pada alat pencuci tangan dahulu, para peNgobeng sendirilah yang membawakan alat pencuci tangan, namun sekarang alat pencuci tangan pun sudah di gantikan dengan wadah yang di isi air kemudian di letakkan di sudut masing-masing, kemudian pada dulang yang digantikan dengan yang lebih mudah ditemukan seperti digantikan dengan yang plastik ${ }^{11}$.

\section{b. Faktor yang Mempengaruhi Pergeseran dan Perubahan Tradisi Ngidang}

Dari pergeseran yang terjadi ada beberapa faktoryang menyebabkan pergeseran Ngidang tersebut terhadap masyarakat kelurahan 30 Ilir, beberapa faktor tersebut penulis membaginya yakni faktor Internal, faktor Eksternal, dan faktor Modernisasi. Berikut beberapa faktor tersebut yang melatarbelakangi terjadinya pergeseran Tradisi Ngidang di Masyarakat 30 Ilir Palembang. Faktor Penyebab Terjadinya perubahan pada tradisi Ngidang. Pada suatu masyarakat, banyak faktor yang menyebakan suatu adat atau tradisi kebudayaan masyarakat bisa mengalami pergeseran serta perubahan, selain karena sifat suatu kebudayaan yang bersifat Dinamis atau berubah-rubah sepanjang waktu ${ }^{12}$. Perubahan itu sendiri dapat dilatarbelakangin beberapa hal baik dari masyarakatnya itu sendiri maupun faktor dari luar, sehingga dapat mempengaruhi suatu keaslian kebudayaan atau tradisi tertentu. ${ }^{13}$

\section{Faktor Perkembangan Zaman}

Hadirnya kebudayaan dari luar memang tidak semuanya mempengaruhi masyarakat, tergantung kepada diri mereka masing-masing. Seperti yang di paparkan informan dari hasil wawancara yang dilakukan penulis ${ }^{14}$. Adanya perkembangan zaman, sekarang suatu masyarakat mau yang praktis dan modern, pemikiran mereka Ngidang itu terlalu rumit dan sudah tertinggal zaman, dan ketika hadirnya prasmanan masyarakat lebih memilih metode tersebut karena penyajian itu lebih modern dan mempermudah" suatu perkembangan zaman sangat mempengaruhi dalam perubahan budaya penyajian masyarakat di kelurahan 30 Ilir Palembang. Modernisasi mempengaruhi suatu perubahan, karena makin berkembanganya suatu masyarakat. Mengakibatkan masyarakat mengikuti perkembangan agar tidak kelihatan ketinggalan zaman oleh masyarakat lainnya.

\section{Faktor Ekonomi}

Faktor ekonomi mempengaruhi adanya perubahan dalam tradisi Ngidang yang dahulu berkembang di masyarakat. Bagi masyarakat 30 Ilir melakukan sesuatu adat-istiadat yang sesuai dengan para pendahulunya tentunya memerlukan biaya yang ekstra untuk saat ini. Menurut hasil pengamatan yang penulis lakukan kepada beberapa informan yang tidak lagi memakai Ngidang saat Penyajian makanan pada Acara-acara Sedekahan. masyarakat

\footnotetext{
${ }^{11}$ Wawancara pribadi dengan bapak R Ahmad. Iskandar (Ketua RT ) Palembang, pada tanggal 04 Januri 2021.

12 Sulasman, Setia Gumilar, Teori-Teori Kebudayaan Dari Teori Hingga Aplikasi, (Bandung: CV. Pustaka Setia, 2018), H. 151.

${ }^{13}$ Soejono Soekanto, Budi Sulistyowati, Sosiologi Suatu Pengantar, (Jakarta: Rajawali Pers, 2017), H

${ }^{14}$ Wawancara pribadi Bapak Suwito, Palembang 04 Januari 2021.
} 
mennganggap Ngidang membutuhkan biaya yang Ekstra untuk menyewa perlengkapan serta banyak membutuhkan tenaga serta membutuhkan cukup tempat yang luas untuk menampung para tamu. Seperti yang di paparkan Ibu Nurbaiti yang di wawancarai oleh penulis ${ }^{15}$.

\section{Faktor Garis Keturunan}

Faktor keturunan disini dimaksudkan adalah berkaitan dengan suku. perbedaan suku sangat memepengaruhi dalam perubahan tradisi Ngidang ini. Masyarakat Palembang yang memiliki gelar ataupun masyarakat yang telah lama menetap di 30 Ilir mereka akan mengerti mengenai adat-adat yang dilaksanakan, sementara mayarakat yang berbeda suku tidak demikian, berbeda pula dengan masyarakat campuran.tidak semua mereka mengetahui apalagi memahami secara cermat seperti yang di paparkan ibu nurbaiti yang merupakan keturunan campuran Jawa dan Palembang, di dalam Keluarga Ibu Nurbaiti Mengenal metode Ngidang dari ibu beliau namun sudah jarang dilakukan. Dan Seperti yang dilakukan oleh bapak R.M. Ali Hanafiah dan bapak R. Ahmad Nawawi sebagai masyarakat yang memiliki gelar beliau mengerti dan perna terlibat dalam kepanitiaan Tradisi Ngidang sebagai tujuan melestarikan warisan budaya.

4. Faktor Modernisasi

Modernisasi juga menjadi faktor pendorong suatu perubahan dalam gaya hidup masyarakat. Melalui perkembangan rasio manusia, masyarakat pun membangun peradaban baru yang disebut dengan era modernisasi. Dalam suatu modernisasi, unsur-unsur yang lama digantikan dengan unsur-unsur yang baru yang dianggap masyarakat lebih modern dan maju, sehingga masyarakat juga cenderung lebih mengikuti perilaku yang baru ketimbang dengan tradisi atau norma kebiasaan. Oleh karena itu masyarakat modern sering meninggalan nilai-nilai tradisonal atau budaya asli mereka ${ }^{16}$. Dengan demikian masyarakat Palembang di kelurahan 30 Ilir mengalami modernisasi dalam kehidupan, dengan adanya modernisasi dalam suatu masyarakat meningkatkan pola pikir masyarakat, serta kecendrungan masyarakat yang mengikuti suatu hal yang baru membuat nilai-nilai tradisonal dan budaya asli masyarakat Palembang menjadi memudar dengan ketertarikan masyarakat, dan sikap yang terbuka dengan hadirnya budaya barat, membuat terjadinya pergeseran serta perubahan Tradisi Ngidang.

c. Dampak perubahan dan pergeseran pada tradisi Ngidang terhadap masyarakat 30 Ilir Palembang.

Adanya perubahan dan pergeseran yang terjadi dalam tradisi Ngidang menimbulkan dampak positif dan negatif yaitu :

1. Dampak Negatif

a) Lemahnya intensitas interaksi masyarakat

Karena semakin adanya pergeseran di dalam penyajian dari "Ngidang" ke prasmanan atau Prancisan serta hadirnya catering prasmanan membuat tradisi lokal semakin terkikis dan ruang lingkup masyarakat dalam berinteraksi akan semakin sedikit dan terkikis. Adanya pergeseran tersebut menyebabkan antusiasme masyarakat terutama remaja di zaman sekarang dalam tradisi Ngidang ketika dilaksanakan oleh masyarakat pelaksanaanya. Mengakibatkan berkurangnya intensitas pertemuan dan kerjasama untuk berinteraksi antara pihak remaja dan orang tua yang menyebabkan kesempatan untuk bercengkrama sangat berkurang.

b) Hubungan antar masyarakat tidak kuat

\footnotetext{
${ }^{15}$ Wawancara Pribadi Dengan Ibu Nurbaiti (warga) pada tanggal 15 Februari 2021

${ }^{16}$ Sri Muhammad Kusumantoro, Perubahan Sosial H. 40
} 
Melalui tradisi Ngidang masyarakat Palembang, mempunyai hubungan yang sangat hangat sesama masyarakat yang lainnya, menurut informasi yang didapatkan dari informan bernama Bapak Sukirman. Beliau memaparkan karena adanya suatu pergeseran metode penyajian makanan yang dari tradisonal ke metode barat yang dinilai lebih modern. Yang dimana pada saat metode Ngidang ini digunakan sebagai metode penyajian masyarakat di Kelurahan 30 Ilir melalui tradisi ini masyarakat saling bertemu dan berinteraksi, Dari sanalah interaksi antara masyarakat terjalin ${ }^{17}$.

Semakin adanya sebuah pergeseran yang ada dalam masyarakat yang berdampak pada masyarakat yang dari masyarakat sosial menjadi masyarakat yang individual dan kurang nya interaksi sesama masyarakat lainnya, saat adanya nya hajatan atau kedurian yang diadakan masyarakat. Sikap saling bergantung serta saling membutuhkan yang terwujud nyata dalam beberapa aktifitas saat Tradisi Ngidang semakin terkikis. Dengan sikap masyarakat menginginkan sesuatu yang praktis, efektif membuat secara tidak langsung nilai-nilai kekeluargaan, kebersamaan, dan kerjasama. Serta kekhasan yang ada pada tradisi Ngidang terkikis serta tergantikan dengan yang modern.

c) Menjadikan Hilangnya budaya lokal atau tradisi yang dimiliki masyarakat sebagai ciri khas masyarakat Melayu Palembang

Hadirnya budaya barat membuat terkikisnya keasliaan budaya lokal sebagai ciri khas masyarakat melayu Palembang. Sehinggga terjadinya pergeseran-pergeseran nilai pada budaya penyajian yang ada di Palembang. Dan menyebabkan menipisnya serta dalam kondisi yang sudah modern saat ini dengan budaya penyajian barat prasmanan atau perancisan yang dinilai masyarakat saat ini lebih efektif dan memudahkan masyarakat dalam melakukan penyajian makanan dalam acara-acara yang masyarakat kelurahan 30 Ilir Palembang saat acara pernikahan, maupun kedurian.

\section{Dampak Positif}

Dengan adanya perkembangan zaman dan perubahan pola pikir masyarakat mengakibatkan adanya perubahan itu yaitu kemajuan pola pikir masyarakat di Kelurahan 30 Ilir Palembang, berkembangnya teknologi yang membantu meningkatkan penghasilan masyarakat dengan menciptakan usaha seperti catering prancisan dan prasmanan, dan memberikan lapangan pekerjaaan untuk masyarakat.

Dari uraian yang penulis uraikan diatas dapat disimpulkan bahwa perubahan global telah banyak merubah sebuah tatanan nilai dalam skala lokal maupun nasional, ada perubahan yang bersifat positif maupun yang bersifat negatif. Dengan hadirnya kebudayaan barat yang merubah kebudayaan lokal secara terus menerus membuat nilai-nilai budaya lokal yang menjadi warisan nenek moyang secara turun menurun mulai hilang dan terkikis. Yang merupakan sebuah wujud nyata dari efek darisebuah perubahan dan pergeseran yang terjadi.

\section{E. KESIMPULAN DAN SARAN}

\section{Kesimpulan}

Tradisi Ngidang merupakan tradisi masyarakat melayu Palembang yang ada di Palembang sejak masa kesultanan Palembang Darussalam yang bercorak Islam, dalam memuliakan para tamu pada saat acara pernikahan, atau kedurian. Tradisi Ngidang ini merupakan tradisi yang banyak nilai-nilai islam yang terkandung antara lain: nilai kebersamaan, nilai kesopanan, dan menghormati orang lebih tua. Selain mengandung banyak nilai-nilai islam didalamnya Tradisi Ngidang ini juga merupakan sunah yang diajarkan Nabi Muhammad SAW. Namun dengan adanya perkembangan zaman masuknya budaya dari luar dan faktor-faktor seperti ekonomi,

\footnotetext{
${ }^{17}$ Wawancara pribadi, bapak Sukirman, Palembang 04 Januari 2021
} 
lingkungan, serta keturunan dan faktor modernisasi yang mengakibatkan tradisi tersebut tergeser dengan budaya barat yang di kenal dengan prasmanan atau prancisan mengakibatkan masyarakat kehilangan kekhasan nya dalam menjamu tamu dalam bentuk penyajian makanan Ngidang. Perubahan serta pergeseran yang terjadi menimbulakan dampak negatif dan positif, antara lain dampak negatif Lemahnya intensitas interaksi masyarakat, Hubungan antar masyarakat tidak kuat, Menjadikan Hilangnya budaya lokal atau tradisi yang dimiliki masyarakat sebagai ciri khas masyarakat Melayu Palembang.

\section{Saran}

Dari penelitian yang telah dilakukan, penulis memberi saran kepada masyarakat sumatera selatan terutama masyarakat kelurahan 30 Ilir Palembang, agar senantiasa menjaga, dan mengembangkan budaya asli Palembang dalam penyajian makanan sebagai budaya lokal Palembang.

Kepada pemerintahan Palembang maupun pemerintah kelurahan 30 Ilir Palembang bahwa diharapakan peransertanya untuk melaukan perkenalan melaluin di bentuknya wadah-wadah kreatifitas untuk para remaja untuk mengenal tradisi lokal Palembang agar warisan warisan budaya lokal yang ada di masyarakat tetap terjaga.

\section{DAFTAR PUSTAKA}

Kusumantoro, Sri Muhammad, Perubahan Sosial. Surakarta: Aksara Sinergi Media. 2018 Nawiyanto, Endrayadi, Eko Crys, Kesultanan Palembang Darussalam Sejarah dan Warisan budayanya. Jember: Jember University Press. 2016.

Sulasman, Gumilar, Setia. Teori-teori Kebudayaan dari teori hingga aplikasi. Bandung: Pustaka Setia. 2013.

Sudarma, I Wayan, Dkk. Budaya Kuliner Ayam Taliwang di Lombok. Yogyakarta: Ombak. 2014

Soekamto, Soerjono. Sulistyowati, Budi. Sosiologi Suatu Pengantar. Jakarta: Rajawali Pers. 2017.

Dona Apriyanti, "Tradisi Mapacci dalam perkawian Masyarakat Bugis Di desa Tanjung Kerang Kec. Babat Supat Kab. Muba. Skripsi: Fakultas Adab dan Humaniora. 2018.

Raka Efriansyah, "Tradisi Nyereka Agok an Di desa Tanjung Makmur Kab.Empat Lawang (Telaah Historis-Antropologi). Skripsi: Fakultas Adab dan Humaniora. 2019.

Choirul Niswah, Tradisi Ruwahan Masyarakat Melayu Palembang Dalam Prespektif Fenomenologi. Jurnal Kebudayaan dan Sastra Islam: Vol. 18. No. 2. 2018.

Fitriah,"Nilai Kearifan Lokal dalam Tradisi "Ngobeng" di desa seri bandung Kec. Tanjung Batu Kab.Ogan Ilir. Jurnal Kebudayaan dan Satra Islam: Vol.19.No.2.2019. 